American Journal of Animal and Veterinary Sciences 8 (2): 98-103, 2013

ISSN: $1557-4555$

(C) 2013 G.U. Zaman et al., This open access article is distributed under a Creative Commons Attribution

(CC-BY) 3.0 license

doi:10.3844/ajavssp.2013.98.103 Published Online 8 (2) 2013 (http://www.thescipub.com/ajavs.toc)

\title{
Molecular Characterization of Assam Hill Goat
}

\author{
Galib Uz Zaman, Naba Nahardeka, \\ Subimal Laskar, Ali Mohomad Ferdoci and Arun Jyoti Chetri
}

Department of Animal Genetics and Breeding, College of Veterinary Science, Assam Agricultural University, Khanapara, Guwahati-781022, Assam, India

Received 2013-05-02, Revised 2013-06-12; Accepted 2013-07-13

\begin{abstract}
A total of 23 polymorphic microsatellite markers were used to evaluate genetic diversity and population structure in Assam Hill Goat (AHG). All the loci studied were polymorphic in nature. The number of observed alleles $\left(\mathrm{N}_{\mathrm{a}}\right)$ detected ranged from 2 to 10 with an overall mean of $4.9 \pm 2.220$. A total of 114 alleles were observed across all the loci. The effective number of alleles $\left(\mathrm{N}_{\mathrm{e}}\right)$ ranged from 1.035 to 7.127 with a mean of $2.68 \pm 1.590$. The allele frequency ranged from 0.013 to 0.982 . The overall mean observed $\left(\mathrm{H}_{\mathrm{O}}\right)$ and expected $\left(\mathrm{H}_{\mathrm{e}}\right)$ heterozygosity were 0.43 and 0.48 respectively and this population was in Hardy-Weinberg equilibrium at most of the loci studied. The overall mean of within-population inbreeding estimate $\left(\mathrm{F}_{\mathrm{IS}}\right)$ was 0.085 . The population was stable with respect to size and was non-bottlenecked. The observed normal L-shaped curve indicated no mode shift in the population.
\end{abstract}

Keywords: Assam Hill Goat, Heterozygosity, PIC, Microsatellites

\section{INTRODUCTION}

Genetic diversity is necessary for the long-term survival of the species and populations because it provides the raw material for adoption and evolution, especially when environmental conditions have changed (Rajora and Mosseler, 2001). The genetic markers are playing important role in measuring genetic diversity. These have been used to find out evolutionary relationship within and between species, genera or higher taxonomic categories (Paterson et al., 1991). Goat is one of the significant food sources, because it can convert feed dry matter into milk as efficiently as other ruminants. The goat population in North East India was approximately $3.51 \%$ of the total India population (Feroze et al., 2010).

The Assam Hill goat (AHG) is an important meat type animal with high prolificacy from the North Eastern region of India. Most common colours of this goat is white, however, brown, black and mixed colour are not uncommon (Fig. 1). They are distributed in the hilly terrain of North Cachar hill, Karbi Anglong districts of Assam and also in the adjoining hilly tract of Meghalaya state.

The Network Project on Animal Genetic ResourcesCore laboratory, Department of Animal Genetics and Breeding, College of Veterinary Science, Assam Agricultural University, Khanapara, Guwahati, Assam, India has undertaken molecular characterization of livestock through microsatellite markers. Onto date no studies are conducted in AHG population from North East India using microsatellites.

In view of this the present study has been planned to investigate genetic variation and population structure within AHG population using 23 polymorphic microsatellite markers.

Corresponding Author: Galib Uz Zaman, Department of Animal Genetics and Breeding, College of Veterinary Science, Assam Agricultural University, Khanapara, Guwahati-781022, Assam, India Tel: 91-9435046150 


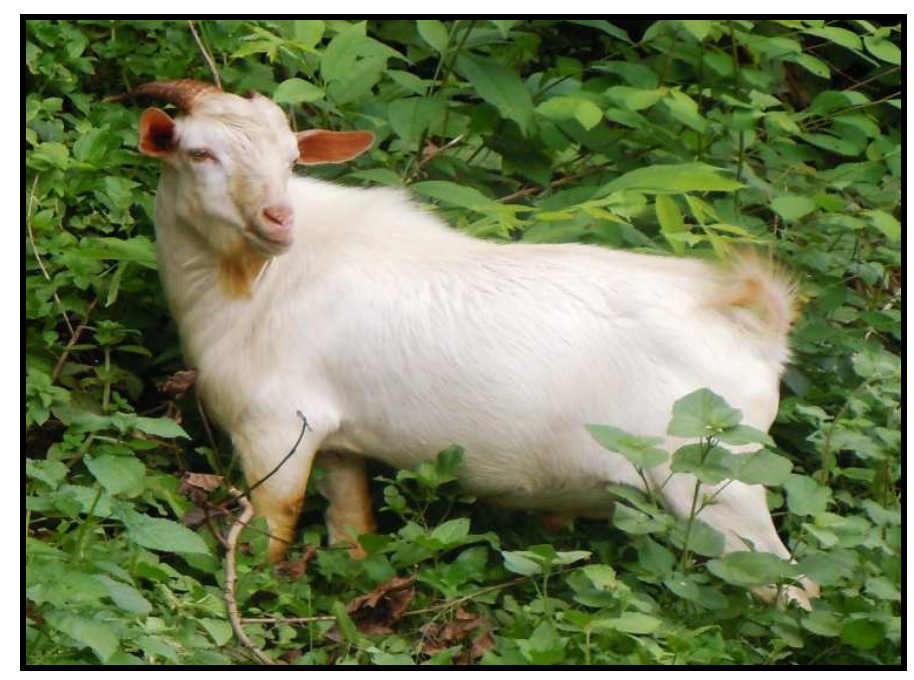

Fig. 1. Figure showing a typical Assam Hill goat (Doe)

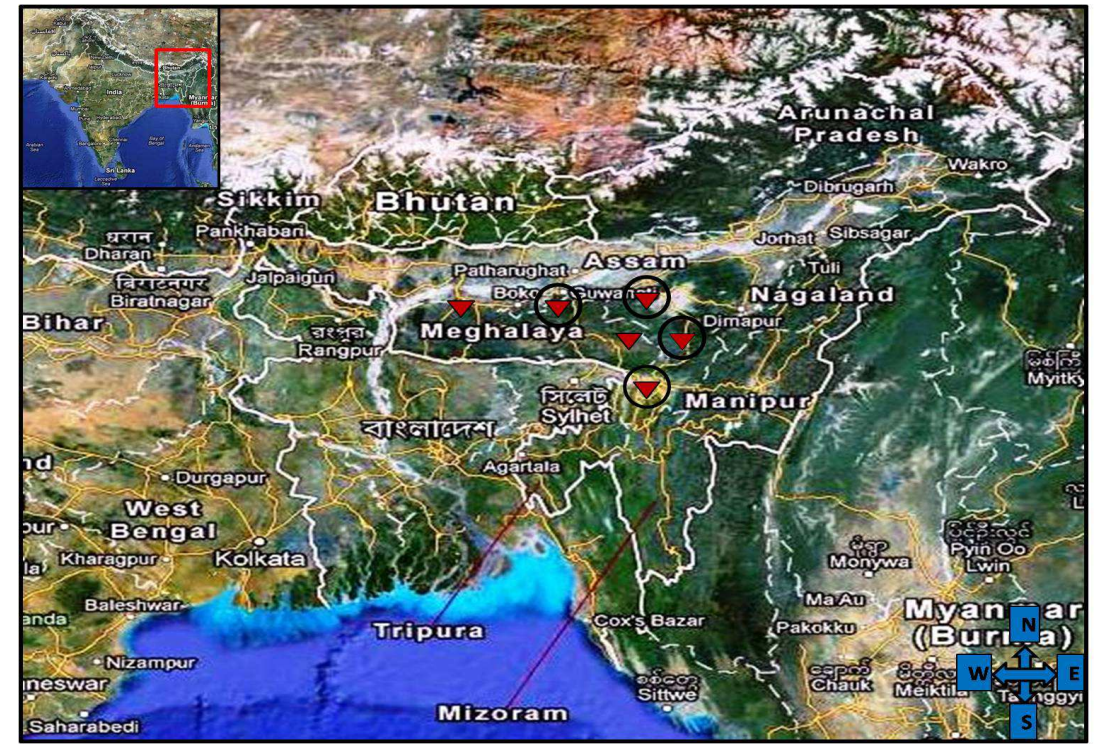

Fig. 2. Figure showing the breeding tract of Assam Hill Goat (AHG) and major sampling sites (Kindness to Google earth map)

\section{MATERIALS AND METHODS}

\subsection{Sample Collection and DNA Isolation}

A total of 40 blood samples of AHG were collected randomly from genetically unrelated individuals from their native breeding tract (Fig. 2).

Blood was collected aseptically into BD vacutainers $(6 \mathrm{~mL})$ containing $\mathrm{K} 2$ EDTA $(10.8 \mathrm{mg})$ and samples were transported to the laboratory on ice and were stored at $4^{\circ} \mathrm{C}$ until use.
Genomic DNA was extracted from the blood samples using standard phenol-chloroform method (Sambrook et al., 1989) with few modifications. All extracted samples were conformed through horizontal electrophoresis on $0.8 \%$ agarose gel containing ethidium bromide. The quantification of DNA was done by Nano-drop spectrophotometer at $260 \mathrm{~nm}$. The concentrated samples were diluted to reach appropriate concentrations $\left(20-50 \mathrm{ng} \mu \mathrm{L}^{-1}\right)$ for the purpose of PCR amplification. 
$\underline{\text { Table 1. Details of microsatellite markers }}$

\begin{tabular}{|c|c|c|c|c|c|c|c|c|}
\hline \multirow[b]{2}{*}{ Locus } & \multirow{2}{*}{$\begin{array}{l}\text { Gene bank } \\
\text { Accession } \\
\text { Number }\end{array}$} & \multirow{2}{*}{$\begin{array}{l}{ }^{* *} \mathrm{Ch} . \\
\text { No }\end{array}$} & \multirow[b]{2}{*}{$\begin{array}{l}\text { *Repeat } \\
\text { motif }\end{array}$} & \multirow[b]{2}{*}{ Primer sequences $\left(5^{\prime} \rightarrow 3^{\prime}\right)$} & \multirow[b]{2}{*}{ Dye } & \multirow[b]{2}{*}{$\mathrm{T}_{\mathrm{a}}\left({ }^{\circ} \mathrm{C}\right)$} & \multicolumn{2}{|c|}{ Size range (bp) } \\
\hline & & & & & & & $\begin{array}{l}* \text { in source } \\
\text { reference }\end{array}$ & $\begin{array}{l}\text { in present } \\
\text { study }\end{array}$ \\
\hline ILSTS008 & L23483 & 14 & $(\mathrm{CA})_{12}$ & $\begin{array}{l}\text { F-GAATCATGGATTTTCTGGGG } \\
\text { R-TAGCAGTGAGTGAGGTTGGC }\end{array}$ & FAM & 58 & $167-195$ & $168-178$ \\
\hline ETH225 & Z14043 & 14 & $(\mathrm{CA})_{18}$ & $\begin{array}{l}\text { F-GATCACCTTGCCACTATTTCCT } \\
\text { R-ACATGACAGCCAAGCTGCTACT }\end{array}$ & VIC & 58 & $146-160$ & $145-147$ \\
\hline OarHH64 & $212^{\mathrm{a}}$ & 4 & Ann & $\begin{array}{l}\text { F-CGTTCCCTCACTATGGAAAGTTATATATGC } \\
\text { R-CACTCTATTGTAAGAATTTGAATGAGAGC }\end{array}$ & PET & 60 & $120-138$ & $121-131$ \\
\hline ILSTS044 & L37259 & Ann & $(\mathrm{GT})_{20}$ & $\begin{array}{l}\text { F-AGTCACCCAAAAGTAACTGG } \\
\text { R-ACATGTTGTATTCCAAGTGC }\end{array}$ & NED & 54 & $145-177$ & $153-171$ \\
\hline ILSTS059 & L37266 & 13 & $(\mathrm{CA})_{4}(\mathrm{GT})_{2}$ & $\begin{array}{l}\text { F-GCTGAACAATGTGATAGTTCAGG } \\
\text { R-GGGACAATACTGTCTTAGATGCTGC }\end{array}$ & FAM & 54 & $105-135$ & $106-120$ \\
\hline OarAE129 & L11051 & 5 & Ann & $\begin{array}{l}\text { F-AATCCAGTGTGTGAAAGACTAATCCAG } \\
\text { RGTAGATCAAGATATAGAATATTTTTCAACACC }\end{array}$ & FAM & 54 & $130-178$ & $149-167$ \\
\hline ILSTS002 & L23479 & Ann & $(\mathrm{CA})_{17}$ & $\begin{array}{l}\text { F-TCTATACACATGTGCTGTGC } \\
\text { R-CTTAGGGGTGTATTCCAAGTGC }\end{array}$ & VIC & 50 & $113-135$ & $114-124$ \\
\hline ILSTS065 & L37269 & 24 & $(\mathrm{CA})_{22}$ & $\begin{array}{l}\text { F-GCTGCAAAGAGTTGAACACC } \\
\text { R-AACTATTACAGGAGGCTCCC }\end{array}$ & PET & 60 & $105-135$ & $116-118$ \\
\hline OarJMP29 & U30893 & Ann & $(\mathrm{CA})_{21}$ & $\begin{array}{l}\text { F-GTATACACGTGGACACCGCTTTGTAC } \\
\text { R-GAAGTGGCAAGATTCAGAGGGGAAG }\end{array}$ & NED & 60 & $120-140$ & $114-116$ \\
\hline ILSTS019 & L23492 & Ann & $(\mathrm{TG})_{10}$ & $\begin{array}{l}\text { F-AAGGGACCTCATGTAGAAGC } \\
\text { R-ACTTTTGGACCCTGTAGTGC }\end{array}$ & FAM & 60 & $142-162$ & $146-158$ \\
\hline ILSTS033 & L37213 & 12 & $(\mathrm{CA})_{12}$ & $\begin{array}{l}\text { F-TATTAGAGTGGCTCAGTGCC } \\
\text { R-ATGCAGACAGTTTTAGAGGG }\end{array}$ & PET & 60 & $151-187$ & $156-178$ \\
\hline ILSTS005 & L23481 & 10 & $(\mathrm{nn})_{39}$ & $\begin{array}{l}\text { F-GGAAGCAATGAAATCTATAGCC } \\
\text { R-TGTTCTGTGAGTTTGTAAGC }\end{array}$ & VIC & 58 & 174-190 & $175-187$ \\
\hline ILSTS058 & Ann & Ann & Ann & $\begin{array}{l}\text { F: GCCTTACTACCATTTCCAGC } \\
\text { R: CATCCTGACTTTGGCTGTGG }\end{array}$ & PET & 54 & $136-188$ & $136-188$ \\
\hline ILSTS087 & L37279 & Ann & $(\mathrm{CA})_{14}$ & $\begin{array}{l}\text { F-AGCAGACATGATGACTCAGC } \\
\text { R-CTGCCTCTTTTCTTGAGAGC }\end{array}$ & NED & 54 & $142-164$ & $139-159$ \\
\hline ILSTS030 & L37212 & 2 & $(\mathrm{CA})_{13}$ & $\begin{array}{l}\text { F-CTGCAGTTCTGCATATGTGG } \\
\text { R-CTTAGACAACAGGGGTTTGG }\end{array}$ & FAM & 60 & $159-179$ & $161-173$ \\
\hline ILSTS034 & L37254 & 5 & $(\mathrm{GT})_{29}$ & $\begin{array}{l}\text { F-AAGGGTCTAATGCCACTGGC } \\
\text { R-GACCTGGTTTAGCAGAGAGC }\end{array}$ & VIC & 58 & $153-185$ & $157-161$ \\
\hline ILSTS029 & L37252 & 3 & $(\mathrm{CA})_{19}$ & $\begin{array}{l}\text { F-TGTTTGATGGAACACAGCC } \\
\text { R-TGGATTTAGACCAGGGTTGG }\end{array}$ & PET & 60 & 148-191 & $153-177$ \\
\hline ILSTS049 & L37261 & 11 & $(\mathrm{CA})_{26}$ & $\begin{array}{l}\text { F-CAATTTTCTTGTCTCTCCCC } \\
\text { R-GCTGAATCTTGTCAAACAGG }\end{array}$ & NED & 58 & $160-184$ & 161-171 \\
\hline OarVH72 & L12548 & 7 & Ann & $\begin{array}{l}\text { F-GGCCTCTCAAGGGGCAAGAGCAGG } \\
\text { R-CTCTAGAGGATCTGGAATGCAAAGCTC }\end{array}$ & VIC & 54 & $108-144$ & $119-121$ \\
\hline OarFCB48 & M82875 & 17 & $(\mathrm{CT})_{10}$ & $\begin{array}{l}\text { F-GAGTTAGTACAAGGATGACAAGAGGCAC } \\
\text { R-GACTCTAGAGGATCGCAAAGAACCAG }\end{array}$ & VIC & 54 & $149-181$ & 146-164 \\
\hline OarHH35 & L12554 & 7 & Ann & $\begin{array}{l}\text { F-AATTGCATTCAGTATCTTTAAACATCTGGC } \\
\text { R-ATGAAAATATAAAGAGAATGAACCACACACGG }\end{array}$ & PET & 54 & $92-112$ & $96-98$ \\
\hline OarFCB304 & L01535 & Ann & $(\mathrm{CT})_{11}(\mathrm{CT})_{15}$ & $\begin{array}{l}\text { F-CCCTAGGAGCTTTCAATAAAGAATCGG } \\
\text { R-CGCTGCTGTCAACTGGGTCAGGG }\end{array}$ & FAM & 54 & $119-179$ & $124-172$ \\
\hline OMHC1 & $228^{\mathrm{a}}$ & Ann & Ann & $\begin{array}{l}\text { F-ATCTGGTGGGCTACAGTCCATG } \\
\text { R-GCAATGCTTTCTAAATTCTGAGGAA }\end{array}$ & NED & 58 & 179-209 & $184-200$ \\
\hline
\end{tabular}

\subsection{Microsatellite Analysis}

All the 23 microsatellite markers were selected from the list recommended by International Society for Animal Genetics (ISAG) and FAO's (DAD-IS) for Caprine, based on their level of polymorphism, allele size range and reliability of allele calling. The forward primer of each marker was fluorescently labeled with either FAM, NED,
PET or VIC dye. All microsatellite markers were first checked under single locus amplification conditions to evaluate their performance in the multiplex and accordingly multiplex panels were prepared. Details of markers used in the present study are shown in Table 1.

Multiplex PCR has been used for multicolor fluorescence genotyping. Based on the guide lines of (Henegariu et al., 1997) the initial parameters of 
multiplex PCR were set up. The basic PCR solution (15 $\mu \mathrm{L}$ ) containing $20-50 \mathrm{ng}$ of template DNA; $1.5 \mathrm{mM}$ $\mathrm{MgCl}_{2} ; 5$ picomoles each of forward and reverse primers; 1 unit of taq DNA polymerase and $200 \mathrm{mM}$ dNTPs was prepared. Amplification was carried out with initial denaturation at $95^{\circ} \mathrm{C}$ for 2 min followed by 30 cycles of denaturation $\left(95^{\circ} \mathrm{C}\right.$ for $\left.30 \mathrm{sec}\right)$, annealing $(54$ to $60^{\circ} \mathrm{C}$ for $\left.30 \mathrm{sec}\right)$ and extension $\left(72^{\circ} \mathrm{C}\right.$ for $\left.45 \mathrm{sec}\right)$. PCR conducted on an Applied Biosystems (Model \#: 9902) Veriti $^{\mathrm{TM}}$ 96-well thermal cycler.

After conformation of magnified PCR products on $2 \%$ agarose gel, genotyping was carried out on automated DNA Sequencer (ABI PRISM $3130 \mathrm{XL}$ ). The resulting data were analyzed using standard software Gene Mapper ${ }^{\mathrm{TM}}$ version 4.0 (Applied Biosystems Inc., California, USA) to generate genotype calls for each locus by using GS 500 (-250) LIZ as size standard.

\subsection{Information Analysis}

POPGENE version 1.31 (Yeh et al., 1999) was used to calculate the allele frequencies, effective number of alleles $\left(\mathrm{N}_{\mathrm{e}}\right)$, observed $\left(\mathrm{H}_{\mathrm{o}}\right)$ and expected $\left(\mathrm{H}_{\mathrm{e}}\right)$ heterozygosity, F-statistics, Shanon's information index (I) and to test of Hardy-Weingberg Equilibrium (HWE). Nei's formula (Nei, 1978) was used to calculate Polymorphic Information Content (PIC). The BOTTLENECK version 1.2.03 (Cornuet and Luikart, 1996) analysis was performed to know whether this goat population exhibits a significant number of loci with excess of heterozygosity.

\section{RESULTS}

The various parameters of genetic differentiation in AHG, such as allele number, effective number of allele, PIC, observed and expected heterozygosity, withinpopulation inbreeding estimate $\left(\mathrm{F}_{\mathrm{IS}}\right)$ and Shanon's information index are furnished in Table 2.

All the 23 loci investigated were polymorphic in nature. The number of observed alleles $\left(\mathrm{N}_{\mathrm{a}}\right)$ detected ranged from 2 (ETH225, ILSTS065, OarJMP29 and ILSTS34) to 10 (OarFCB304), with an overall mean of $4.90 \pm 2.220$ and a total of 114 alleles were observed at these loci in the population. However, the effective number of alleles $\left(\mathrm{N}_{\mathrm{e}}\right)$ ranged from 1.035 to 7.127 with a mean of $2.68 \pm 1.590$. Overall allele frequency ranged from 0.013 (at locus ILSTS33) to 0.982 (at locus ETH225). The PIC value ranged from 0.033 (ETH225) to 0.843 (OMHC1) with a mean of $0.44 \pm 0.263$. The overall means for observed $\left(\mathrm{H}_{\mathrm{O}}\right)$ and expected $\left(\mathrm{H}_{\mathrm{e}}\right)$ heterozygosities were $0.43 \pm 0.285$ and $0.48 \pm 0.281$, respectively which ranged from 0.034 (ETH225) to 0.862 (ILSTS002) and 0.033 (ETH225) to 0.859 $(\mathrm{OMHC} 1)$ respectively. The chi-square $\left(\chi^{2}\right)$ test for HWE revealed that 10 out of 23 loci deviated from equilibrium. Shannon's information index (I) (Lewontin, 1995), which measures the level of diversity, was sufficiently high with a mean of $1.00 \pm 0.606$. The within population inbreeding estimates $\left(\mathrm{F}_{\mathrm{IS}}\right)$ observed at 10 loci were positive which ranged from 0.012 (OarHH64) to 0.771 (OARE129). Only 13 loci revealed negative $F_{\text {IS }}$ values indicating the absence of inbreeding in these loci. The mean $F_{I S}$ value observed was 0.085 . Though positive $F_{I S}$ values were observed at 10 loci, only $8.5 \%$ of inbreeding was recorded in AHG.

Three mutation models namely, Infinite Allele Model (IAM), Two Phase Model (TPM), Stepwise Mutation Model (SMM) were used for Bottleneck analysis (Table 3). In AHG population, under Sign test, the expected number of loci with heterozygosity excess were 8.93 (TPM) and 9.07 (SMM) which are respectively higher than the observed number of loci 6 (TPM) and 4 (SMM) with heterozygosity excess. The expected number of loci (8.67) with heterozygosity excess was not significantly $(p>0.05)$ higher than the observed number of loci (9) with heterozygosity excess under IAM. Standard difference test (T2 statistics) in this population provided the significant gene diversity deficit under the three mutation models IAM (-0.794), TPM (-2.751) and SMM (-6.447) respectively. Under Wilcoxon rank test, probability values of 0.701 (IAM), 0.974 (TPM) and 0.999 (SMM) were non-significant. The mode shift analysis revealed L-shaped curve indicating no mode-shift in the frequency distribution of alleles. The graphical representation of mode-shift has been shown in Fig. 3.

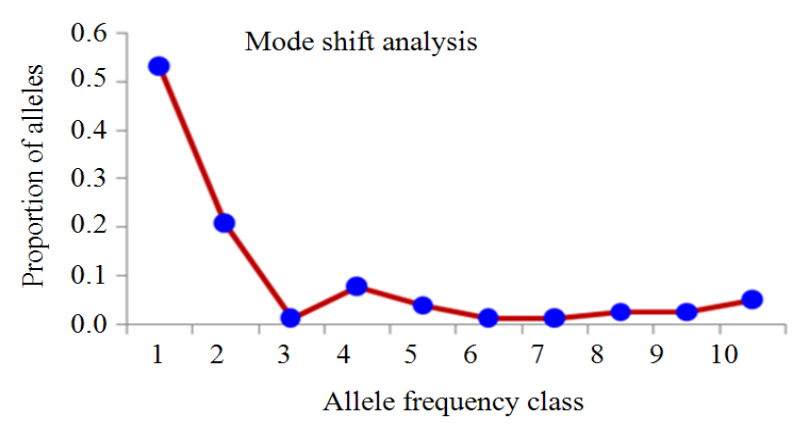

Fig. 3. Figure showing the graphical representation of allele proportions and their contribution in Assam Hill Goat (AHG) 
Table 2. Microsatellite analysis in Assam Hill Goat (AHG)

\begin{tabular}{|c|c|c|c|c|c|c|c|c|c|}
\hline \multirow[b]{2}{*}{ Panel } & \multirow[b]{2}{*}{ Locus } & \multicolumn{8}{|c|}{ Parameters } \\
\hline & & $\mathrm{N}_{\mathrm{a}}$ & $\mathrm{N}_{\mathrm{e}}$ & PIC & $\mathrm{H}_{\mathrm{O}}$ & $\mathrm{H}_{\mathrm{e}}$ & $\mathrm{F}_{\mathrm{IS}}$ & HWE & I \\
\hline \multirow[t]{4}{*}{ Panel 1} & ILSTS008 & 4 & 1.5898 & 0.3383 & 0.3793 & 0.3710 & -0.0224 & $1.185^{\mathrm{NS}}$ & 0.7092 \\
\hline & ETH225 & 2 & 1.0351 & 0.0333 & 0.0345 & 0.0339 & -0.0175 & $0^{\mathrm{NS}}$ & 0.0871 \\
\hline & OarHH64 & 6 & 3.3176 & 0.6472 & 0.6897 & 0.6986 & 0.0128 & $19.73^{\mathrm{NS}}$ & 1.3707 \\
\hline & ILSTS044 & 4 & 1.1110 & 0.0983 & 0.1034 & 0.0999 & -0.0357 & $0.056^{\mathrm{NS}}$ & 0.2604 \\
\hline \multirow[t]{5}{*}{ Panel 2} & ILSTS059 & 5 & 2.2517 & 0.4860 & 0.4483 & 0.5559 & 0.1936 & $25.12 * *$ & 1.0155 \\
\hline & OarE129 & 6 & 4.4122 & 0.5803 & 0.1765 & 0.7734 & 0.7718 & $79.25 * *$ & 1.6226 \\
\hline & ILSTS002 & 6 & 3.7130 & 0.6872 & 0.8621 & 0.7307 & -0.1798 & $79.69 * *$ & 1.4740 \\
\hline & ILSTS065 & 2 & 1.3554 & 0.2278 & 0.3103 & 0.2622 & -0.1837 & $0.85^{\mathrm{NS}}$ & 0.4316 \\
\hline & OarJMP29 & 2 & 1.0713 & 0.0644 & 0.0690 & 0.0666 & -0.0357 & $0.018^{\mathrm{NS}}$ & 0.1500 \\
\hline Panel 3 & ILSTS 033 & 8 & 1.9300 & 0.4652 & 0.5278 & 0.4819 & -0.0953 & $10.21^{\mathrm{NS}}$ & 1.1178 \\
\hline \multirow[t]{4}{*}{ Panel 4} & ILSTS019 & 6 & 3.0036 & 0.6180 & 0.5172 & 0.6671 & 0.2246 & $27.32 *$ & 1.3451 \\
\hline & ILSTS005 & 3 & 1.2752 & 0.1988 & 0.2414 & 0.2158 & -0.1185 & $0.46^{\mathrm{NS}}$ & 0.4178 \\
\hline & ILSTS058 & 6 & 3.0862 & 0.6179 & 0.4483 & 0.6760 & 0.3369 & $29.27 *$ & 1.3084 \\
\hline & ILSTS087 & 7 & 3.5262 & 0.6790 & 0.8276 & 0.7164 & -0.1552 & $80.16^{* *}$ & 1.4948 \\
\hline \multirow[t]{4}{*}{ Panel 5} & ILSTS030 & 7 & 5.1429 & 0.7792 & 0.7778 & 0.8056 & 0.0345 & $21.93^{\mathrm{NS}}$ & 1.7578 \\
\hline & ILSTS034 & 2 & 1.0571 & 0.0526 & 0.0556 & 0.0540 & -0.0286 & $0^{\mathrm{NS}}$ & 0.1269 \\
\hline & ILSTS029 & 4 & 2.0313 & 0.4640 & 0.6111 & 0.5077 & -0.2036 & $1.58^{\mathrm{NS}}$ & 0.9427 \\
\hline & ILSTS049 & 5 & 3.5801 & 0.6728 & 0.8333 & 0.7207 & -0.1563 & $14.49^{\mathrm{NS}}$ & 1.4003 \\
\hline \multirow[t]{4}{*}{ Panel 6} & OarVH72 & 4 & 1.2675 & 0.2040 & 0.1429 & 0.2110 & 0.3230 & $69.06^{* *}$ & 0.4791 \\
\hline & HH35 & 2 & 1.2462 & 0.1780 & 0.0556 & 0.1975 & 0.7188 & $21.22 * *$ & 0.3488 \\
\hline & OarFCB48 & 5 & 3.2580 & 0.6330 & 0.4571 & 0.6931 & 0.3404 & $19.42 *$ & 1.2730 \\
\hline & OarFCB304 & 10 & 4.3272 & 0.7503 & 0.8056 & 0.7689 & -0.0477 & $35.7^{\mathrm{NS}}$ & 1.8543 \\
\hline Panel 7 & $\mathrm{OMHC1}$ & 8 & 7.1271 & 0.8434 & 0.6207 & 0.8597 & 0.2780 & $65.33 * *$ & 2.0129 \\
\hline \multirow{2}{*}{\multicolumn{2}{|c|}{ Mean overall loci }} & $4.95 \pm$ & $2.68 \pm$ & $0.44 \pm$ & $0.43 \pm$ & $0.48 \pm$ & 0.0850 & & $1 \pm$ \\
\hline & & 2.225 & 1.590 & 0.263 & 0.285 & 0.281 & & & 0.606 \\
\hline
\end{tabular}

* Significant $(\mathrm{p} \leq 0.05)$; **Highly significant ( $\mathrm{p} \leq 0.01) ;{ }^{\text {NS }}$ Not significant ( $\left.\mathrm{p} \geq 0.05\right)$; Na, Number of alleles; Ne, Effective number of alleles; PIC, Polymorphic information content; Ho, Observed Heterozygosity; He, Expected Heterozygosity; $\mathrm{F}_{\mathrm{IS}}$, Deficit or excess of Heterozygotes; HWE, Hardy-Weinberg equilibrium; I, Shannon's Information Index

Table 3. Bottleneck analysis in Assam Hill Goat (AHG)

\begin{tabular}{|c|c|c|c|c|c|}
\hline \multirow[b]{2}{*}{ Model } & \multicolumn{3}{|c|}{ Sign rank test-Number of loci with heterozygosity excess } & \multirow{2}{*}{$\begin{array}{l}\text { Standardized } \\
\text { differences test-T2 } \\
\text { values (probability) }\end{array}$} & \multirow{2}{*}{$\begin{array}{l}\text { Wilcoxon test- } \\
\text { Probability of } \\
\text { heterozygosity excess }\end{array}$} \\
\hline & Expected & Observed & Probability & & \\
\hline IAM & 8.67 & 9 & 0.53699 & $-0.794(0.21351)$ & 0.70171 \\
\hline TPM & 8.93 & 6 & 0.10894 & $-2.751(0.00297)$ & 0.97467 \\
\hline SMM & 9.07 & 4 & 0.01015 & $-6.447(0.00000)$ & 0.99958 \\
\hline
\end{tabular}

IAM-Infinite allele model; TPM-Two phase model; SMM-Stepwise mutation model

\section{DISCUSSION}

The present study revealed that the most of the studied loci were highly informative, indicating high polymorphism. Thus these markers strongly signified genetic diversity investigations of AHG. The number and sizes of microsatellite alleles observed in this study fall within the range mentioned in the Secondary Guidelines for Development of National Farm Animal Genetic Resource Management Plans of FAO. The mean number of alleles observed (4.90) in the present investigation was less than the mean number of alleles reported in Ganjam
(6.29) goat (Sharma et al., 2009) and Gohilwari (10.12) goat (Kumar et al., 2009).

The PIC value in the present investigation ranged from 0.033 to 0.843 which is in close agreement with the reports of (Sharma et al., 2009) in Ganjam goat and (Kumar et al., 2009) in Gohilwari goat. The low observed heterozygosity 0.034 (ETH225) was observed in the present study may be due to the presence of more homozygote individual in the samples analyzed. Though few loci exhibited lower heterozygosity values, most of the loci showed relatively higher expected heterozygosity, which reflects the existence of differentiation in the 
population (Karthickeyan et al., 2008). The chi-square $\left(\chi^{2}\right)$ test revealed that 13 microsatellite loci in the AHG population are in equilibrium. These results established that the samples were drawn from the large random mating population (Karthickeyan et al., 2008).

The overall mean $F_{\text {IS }}(0.085)$ observed in the present study indicated a $8.5 \%$ shortfall of heterozygosity in AHG population which is not significant as compared to heterozygote deficiency reported in Ganjam goat 21.7\% (Sharma et al., 2009); Gohilwari goat 26.4\% (Kumar et al., 2009); Kutchi goat $26 \%$, Mehsana goat $14 \%$ and Sirohi goat $36 \%$ (Dixit et al., 2009). The present findings of $\mathrm{F}_{\mathrm{IS}}$ value supports random mating in the studied population. The main reasons for the random mating are wide range of native breeding tract and sufficient availability of breeding bucks in the population.

Bottleneck analysis revealed that the breed is nonbottelnecked where the mode-shift for the frequency distribution of alleles had a normal L-shaped curve stating that there was no recent and/or sudden reduction in the population.

\section{CONCLUSION}

The PIC values observed in the present study is indicative of the fact that the markers used are highly informative for characterization of AHG diversity. The significant level of variability in this population reflects that the AHG population contains a valuable genetic diversity. The population has not undergone any reduction at least in the recent past. Hence, this population could provide a valuable source of genetic material that may be used for meeting the demands of future breeding programmes.

\section{ACKNOWLEDGEMENT}

The researchers wish to extend their gratitude to the Indian Council of Agricultural Research, New Delhi, India for the financial assistance for molecular characterization work through the Network Projects of the National Bureau of Animal Genetic Resources, Karnal, India.

\section{REFERENCES}

Cornuet, J.M. and G. Luikart, 1996. Description and power analysis of two tests for detecting recent population bottlenecks from allele frequency data. Genetics, 144: 2001-2014.
Dixit, S.P., N.K. Verma, R.A.K. Aggarwal., S. Kumar and R. Chander et al., 2009. Genetic structure and differentiation of three Indian goat breeds. AsianAust. J. Anim. Sci.

Feroze, S.M., V.T. Raju, R. Singh and A.K. Tripathi, 2010. Status of livestock sectorl: A micro study of North Eastern India. Ind. J. Hill Farm., 23: 43-51.

Henegariu, O., N.A. Heerema, S.R. Dlouhy, G.H. Vance and P.H. Vogt, 1997. Multiplex PCR: Critical parameters and step-by-step protocol. Biotechniques, 23: 504-511. PMID: 9298224

Karthickeyan, S.M.K., P. Kumarasamy, S.N. Sivaselvam, R. Saravanan and P. Thangaraju, 2008. Analysis of microsatellite markers in Ongole breed of cattle. Ind. J. Biotech., 7: 113-116.

Kumar, S., S.P. Dixit, N.K. Verma, D.K. Singh and A. Pande et al., 2009. Genetic diversity analysis of the Gohilwari breed of Indian goat (Capra hircus) using microsatellite markers. Am. J. Anim. Vet. Sci., 4: 49-57. DOI: 10.3844/ajavsp.2009.49.57

Lewontin, R.C., 1995. The Apportionment of human diversity. Evol. Biol., 6: 381-398. DOI: 10.1007/978-1-4684-9063-3_14

Nei, M., 1978. Estimation of average heterozygosity and genetic distance from a small number of individuals. Genetics, 89: 583-590.

Paterson, A.H., S.D. Tanksley and M.E. Sorrells, 1991. DNA markers in plant improvement. Adv. Agron., 46: 39-90. DOI: 10.1016/S0065-2113(08)60578-7

Rajora, O.P. and A. Mosseler, 2001. Challenges and opportunities for conservation of forest genetic resources. Euphytica, 118: 197-212. DOI: 10.1023/A.1004150525384.

Sambrook, J., E.F. Fritsch and T. Maniatis, 1989. Molecular Cloning: A Laboratory Manual. 2nd Edn., Cold Spring Harbor Laboratory, Cold Spring Harbor, New York, ISBN-10: 9780879693091.

Sharma, R., A.K. Pandey, B. Prakash, B.P. Mishra and P.K. Singh et al., 2009. Genetic diversity of ganjam goat by microsatellite markers. Ind. Vet. J., 86: 275-277.

Yeh, F.C., T. Boyle, Y. Rongcai, Z. Ye and J.M. Xian, 1999. Popgene. Version 1.31. A Microsoft Windows based freeware for population genetic analysis. University of Alberta, Edmonton. 